\title{
Knowledge, Attitude Related to Cervical Cancer Screening among Women
}

\author{
K. Thavamani* and C. Susila \\ Billroth College of Nursing, Dr. MGR Medical University, Chennai, Tamil Nadu, India \\ *Corresponding author
}

\section{A B S T R A C T}

\begin{tabular}{|l|}
\hline Ke y w o r d s \\
Cervical cancer, \\
Knowledge and \\
Attitude, Cervical \\
screening test
\end{tabular}

\section{Introduction}

Cervical cancer is the second most common cancer in women worldwide and with an estimated 5, 28,000 new cases and approximately 2, 66,000 deaths, accounting for $7.5 \%$ of all female cancer deaths. Global incidence rate 2012, 16 per $1,00,000$ preventure rate 1.41 million, there are 2, 68,000 deaths in the year of 2010 worldwide.

Almost $80 \%$ of the cases occurred in the developing countries, one of the leading causes of gynecological cancer related mortality and morbidity in developing country. Cervical cancer is preventable and treatable disease, early detection has reduced
Cervical cancer mainly caused by human papilloma virus infection, is the leading cancer in Indian women and the second most common cancer in women worldwide. Almost $80 \%$ of cases occurred in developing countries. The objectives of the study were to assess the knowledge, attitude regarding cervical cancer screening test and to associate among the level of knowledge, attitude with their selected demographic variables. It is a Descriptive research with pre experimental design and 95 samples were selected through convenient the knowledge and attitude. The result showed that the participants had inadequate and moderate level of knowledge and attitude. No women had adequate knowledge and positive attitude. There was a significant association found between knowledge and education, contraception, abortion. The study concluded that the women need to be educated about the cervical cancer screening. The investigator distributed the pamphlets regarding cervical cancer to the participants.

mortality in world wide. The Papa Nicola smear is an efficient and effective method of detecting cytological changes in the uterine cervix.

Screening test helps to detect the early cytological changes like dysplasia.

Pap test should start on women aged 30 years or more. The incidence rises in 30-34 years of aged and peaks at 55-65 years.

Western Europe and Australia more than 20 per 100,000. In Melanesia 20.6 per 100,000, Middle East 22.2 per 100,000 and Eastern 27.6 per 100,000. In Indian women, HPV infection is common at 26-35 years of age. 
HPV is associated with 50,000/- new case of cervical cancer and 250,000 associated cervical cancer death worldwide each year.

All sexually active women are infected with at least once during their life. The recent (NCRP 2009 and 2011) aged adjusted rate 24.3 followed by Barshi expanded at 19.5 and Bangalore at 18.9 in Chennai, from 41 to 16.7 in 2009, In Thiruvananthapuram from 9.2 in 2006. The purpose of this study was to assess the knowledge and attitude related to cervical cancer screening among women residing in kattupakam at Chennai women

\section{Statement of the problem}

A study to assess the knowledge, attitude regarding cervical cancer screening test among women residing in kattupakkam, at chennai.

\section{Objectives}

To assess the knowledge and attitude regarding cervical cancer screening test among women.

To associate the level of knowledge and attitude with their selected Demographic variables.

\section{Assumptions}

Women have inadequate knowledge regarding cervical cancer screening.

Knowledge of women is influenced by different variables such as Age, Religion, Marital status, Age at marriage, Type of family, Education, Occupation, Income, source of information.

Pamplet regarding cervical cancer screening will improve the awareness among women regarding cervical cancer screening.

\section{Materials and Methods}

\section{Design}

The design used in the study was non experimental descriptive research design which helps to provide factual information about the variables.

\section{Setting}

The research study was conducted at kattupakkam village, Kanchipuram district, Tamilnadu. It covers about 2,000 women with the age group 18 to 55 years.

Majority of the women are home makers, rest of them work under daily wages.

\section{Inclusion criteria}

All women with age group 18 to 55 years.

The women who lives in kattupakkam villege and can talk Tamil.

\section{Exclusion criteria}

The women who are not willing to participate in this study

\section{Population}

All women with age between 18 to more than 55 years, total 95 women were selected for this study at women residing at Kattupakkam.

\section{Sample and sampling technique}

95 women were selected by convenient sampling method.

\section{Tools}

The semi structured Questionnaire was used for data collection. 
Table.1 Socio -demographics characteristics of the study participants

\begin{tabular}{|l|}
$\begin{array}{l}\text { Characteristics } \\
\text { AGE }\end{array}$ \\
\hline 18 -30 years \\
\hline 31-40 years \\
\hline 41-50 years \\
\hline > 50 years \\
\hline Religion \\
\hline Hindu \\
\hline Christian \\
\hline Muslim \\
\hline Education \\
\hline No education \\
\hline Primary Education \\
\hline Secondary Education \\
\hline Graduat \\
\hline
\end{tabular}

$\frac{\text { Women }(\mathbf{n}=95)}{\mathbf{n}}$

\begin{tabular}{l} 
Graduate \\
\hline Occupation
\end{tabular}

\begin{tabular}{|l|l|}
\hline 23 & 24.2 \\
\hline 30 & 31.6 \\
\hline 24 & 25.3 \\
\hline 18 & 18.9 \\
\hline
\end{tabular}

\begin{tabular}{|l|}
\hline Government Employee \\
\hline Private Employee \\
\hline Self Employment \\
\hline Home Maker \\
\hline
\end{tabular}

\begin{tabular}{|l|l|}
\hline 72 & 75.8 \\
\hline 15 & 15.8 \\
\hline 8 & 8.4 \\
\hline
\end{tabular}

\begin{tabular}{|l|l|}
\hline 13 & 13.7 \\
\hline 25 & 26.3 \\
\hline 39 & 41.1 \\
\hline 18 & 18.9 \\
\hline
\end{tabular}

\begin{tabular}{|l|}
\hline Income \\
\hline Rs $<5000$ \\
\hline Rs $\mathbf{5 0 0 1}-\mathbf{1 0 0 0 0}$ \\
\hline Rs $10001-\mathbf{1 5 0 0 0}$ \\
\hline Rs $>15000$ \\
\hline Marital Status \\
\hline
\end{tabular}

\begin{tabular}{|l|l|}
\hline 6 & 6.3 \\
\hline 8 & 8.4 \\
\hline 25 & 26.3 \\
\hline 56 & 58.9 \\
\hline
\end{tabular}

\begin{tabular}{|l|}
\hline Married \\
\hline Un Married \\
\hline Divorced / Widowed \\
\hline
\end{tabular}

\begin{tabular}{|l|l|}
\hline 15 & 15.8 \\
\hline 33 & 34.7 \\
\hline 23 & 24.2 \\
\hline 24 & 25.3 \\
\hline
\end{tabular}

\begin{tabular}{|l|l|l|}
\hline Age at Marriage & 17 & 17.9 \\
\hline < 20 years & 66 & 69.5 \\
\hline $\mathbf{2 0}$-25 years & 12 & 12.6 \\
\hline > 25 years & & \\
\hline No of Pregnancy & 12 & 12.6 \\
\hline Zero & 17 & 17.9 \\
\hline $\mathbf{1}$ & & \\
\hline
\end{tabular}




\begin{tabular}{|c|c|c|}
\hline 2 & 50 & 52.6 \\
\hline 3 & 16 & 16.8 \\
\hline \multicolumn{3}{|l|}{ Family Type } \\
\hline Nuclear & 86 & 90.5 \\
\hline Joint & 9 & 9.5 \\
\hline \multicolumn{3}{|l|}{ Contraception Used } \\
\hline Yes & 73 & 76.8 \\
\hline No & 22 & 23.2 \\
\hline \multicolumn{3}{|l|}{ No of Abortion } \\
\hline $\mathbf{0}$ & 14 & 14.7 \\
\hline 1 & 16 & 16.8 \\
\hline 2 & 62 & 65.3 \\
\hline 3 & 3 & 3.2 \\
\hline \multicolumn{3}{|l|}{ No of Pregnancy } \\
\hline $\mathbf{0}$ & 13 & 13.7 \\
\hline 1 & 63 & 66.3 \\
\hline 2 & 13 & 13.7 \\
\hline 3 & 6 & 6.3 \\
\hline \multicolumn{3}{|c|}{ Heard about Pap Test } \\
\hline Yes & 65 & 68.4 \\
\hline No & 30 & 31.6 \\
\hline \multicolumn{3}{|c|}{ Source of Knowledge through } \\
\hline Friends / Relatives & 10 & 10.5 \\
\hline Media & 54 & 56.8 \\
\hline Health Workers & 31 & 32.6 \\
\hline \multicolumn{3}{|c|}{ Every women must be take pap smear test } \\
\hline Yes & 54 & 56.8 \\
\hline No & 41 & 43.2 \\
\hline
\end{tabular}

Table.2 Frequency and percentage distribution of level of knowledge and attitude on cervical cancer screening

\begin{tabular}{|c|c|c|c|c|c|}
\hline $\begin{array}{c}\text { Level of } \\
\text { Knowledge }\end{array}$ & Frequency & Percentage & $\begin{array}{c}\text { Level of } \\
\text { Attitude }\end{array}$ & Frequency & Percentage \\
\hline Inadequate & 77.9 & $82 \%$ & poor & 89.9 & $94.6 \%$ \\
\hline Moderate & 17.2 & $18.10 \%$ & better & 5 & $5.26 \%$ \\
\hline Adequate & 0 & $0 \%$ & Positive & 0 & $0 \%$ \\
\hline
\end{tabular}


Table.3 Association of the adequacy knowledge and attitude regarding cervical cancer screening test with social demographic characteristics

\begin{tabular}{|c|c|c|c|c|c|c|c|c|}
\hline & & & & & & & $\mathrm{N}=\mathrm{C}$ & \\
\hline Characteristics & & Knowle & & & & Attitud & & \\
\hline Age & Inadequate & Moderate & $\begin{array}{l}\text { Chi } \\
\text { square }\end{array}$ & $\begin{array}{l}P \\
\text { value }\end{array}$ & Inadequate & $\begin{array}{l}\text { Moderat } \\
\text { e }\end{array}$ & $\begin{array}{l}\text { Chi } \\
\text { square }\end{array}$ & $\begin{array}{l}P \\
\text { value }\end{array}$ \\
\hline $18-30$ & $22(23.2 \%)$ & $1(1.1 \%)$ & & & $22(23.2 \%)$ & $1(1.1 \%)$ & & \\
\hline $31-40$ & $22(23.2 \%)$ & $8(8.4 \%)$ & & & $27(28.4 \%)$ & $3(3.2 \%)$ & & \\
\hline $41-50$ & $19(20.0 \%)$ & $5(5.3 \%)$ & 4.604 & 0.203 & $24(25.3 \%)$ & $0(0 \%)$ & 2.725 & 0.436 \\
\hline$>50$ & $15(15.8 \%)$ & $3(3.2 \%)$ & & & $17(17.9 \%)$ & $1(1.1 \%)$ & & \\
\hline Religion & & & & & & & & \\
\hline Hindu & $55(57.9 \%)$ & $17(17.9 \%)$ & & & $68(71.6 \%)$ & $4(4.2 \%)$ & & \\
\hline Christian & $15(15.8 \%)$ & $0(0 \%)$ & 6.614 & 0.037 & $15(15.8 \%)$ & $0(0 \%)$ & & \\
\hline Muslim & $8(8.4 \%)$ & $0(0 \%)$ & & & $7(7.4 \%)$ & $1(1.1 \%)$ & 1.686 & 0.430 \\
\hline Education & & & & & & & & \\
\hline No education & $6(6.3 \%)$ & $7(7.4 \%)$ & & & $10(10.5 \%)$ & $3(3.2 \%)$ & & \\
\hline $\begin{array}{l}\text { Primary } \\
\text { Education }\end{array}$ & $24(25.3 \%)$ & $1(1.1 \%)$ & 19.357 & 0.000 & $25(26.3 \%)$ & $0(0 \%)$ & 10.235 & 0.017 \\
\hline $\begin{array}{l}\text { Secondary } \\
\text { education }\end{array}$ & $30(31.6 \%)$ & $9(9.5 \%)$ & & & $38(40.0 \%)$ & $1(1.1 \%)$ & & \\
\hline Graduation & $18(18.9 \%)$ & $0(0 \%)$ & & & $17(17.9 \%)$ & $1(1.1 \%)$ & & \\
\hline Occupation & & & & & & & & \\
\hline $\begin{array}{l}\text { Government } \\
\text { Employee }\end{array}$ & $6(6.3 \%)$ & $0(0 \%)$ & & & $6(6.3 \%)$ & $0(0 \%)$ & & \\
\hline Private Employee & $8(8.4 \%)$ & $0(0 \%)$ & & & $8(8.4 \%)$ & $0(0 \%)$ & $1.154 \%$ & 0.764 \\
\hline Self Employment & $17(17.9 \%)$ & $8(8.4 \%)$ & 6.563 & 0.087 & $23(24.2 \%)$ & $2(2.1 \%)$ & & \\
\hline Home maker & $47(49.5 \%)$ & $9(9.5 \%)$ & & & $53(55.8 \%)$ & $3(3.2 \%)$ & & \\
\hline Income & & & & & & & & \\
\hline Rs $<5000$ & $12(12.6 \%)$ & $3(3.2 \%)$ & & & $14(14.7 \%)$ & $1(1.1 \%)$ & & \\
\hline Rs $5001-10000$ & $25(26.3 \%)$ & $8(8.4 \%)$ & 6.788 & 0.079 & $32(33.7 \%)$ & $1(1.1 \%)$ & & \\
\hline Rs $10001-15000$ & $23(24.2 \%)$ & $0(0 \%)$ & & & $23(24,2 \%)$ & $0(0 \%)$ & 4.188 & .242 \\
\hline Rs $>15000$ & $18(18.9 \%)$ & $6(6.3 \%)$ & & & $21(22.1 \%)$ & $3(3.2 \%)$ & & \\
\hline Marital Status & & & & & & & & \\
\hline Married & $70(73.7 \%)$ & $17(17.9 \%)$ & 1.904 & 0.386 & $82(86.3 \%)$ & $5(5.3 \%)$ & & \\
\hline Un Married & $4(4.2 \%)$ & $0(0 \%)$ & & & $4(4.2 \%)$ & $0(0 \%)$ & & 0.785 \\
\hline $\begin{array}{l}\text { Divorced// } \\
\text { Widowed }\end{array}$ & $4(4.2 \%)$ & $0(0 \%)$ & & & $4(4.2 \%)$ & $0(0 \%)$ & .485 & \\
\hline Age at Marriage & & & & & & & & \\
\hline$<20$ & $17(17.9 \%)$ & $0(0 \%)$ & & & $16(16.8 \%)$ & $1(1.1 \%)$ & & \\
\hline $20-25$ & $53(55.8 \%)$ & $13(13.7 \%)$ & 5.798 & 0.055 & $63(66.3 \%)$ & $3(3.2 \%)$ & .308 & 0.857 \\
\hline$>25$ & $8(8.4 \%)$ & $4(4.2 \%)$ & & & $11(11.6 \%)$ & $1(1.1 \%)$ & & \\
\hline No of Pregnancy & & & & & & & & \\
\hline 0 & $12(12.6 \%)$ & $0(0 \%)$ & & & $12(12.6 \%)$ & $0(0 \%)$ & & \\
\hline 1 & $16(16.8 \%)$ & $1(1.1 \%)$ & 14.543 & 0.002 & $17(17.9 \%)$ & $0(0.0 \%)$ & 4.750 & 0.191 \\
\hline 2 & $34(35.8 \%)$ & $16(16.8 \%)$ & & & $45(47.4 \%)$ & $5(5.3 \%)$ & & \\
\hline 3 & $16(16.8 \%)$ & $0(0 \%)$ & & & $16(16.8 \%)$ & $0(0 \%)$ & & \\
\hline Contraception & & & & & & & & \\
\hline Used & $64(67.4 \%)$ & $9(9.5 \%)$ & & & $72(75.8 \%)$ & $1(1.1 \%)$ & & \\
\hline Not used & $14(14.7 \%)$ & $8(8.4 \%)$ & 6.647 & 0.010 & $18(18.9 \%)$ & $4(4.2 \%)$ & 9.583 & 0.002 \\
\hline Type of Family & & & & & & & & \\
\hline
\end{tabular}




\begin{tabular}{|c|c|c|c|c|c|c|c|c|}
\hline Nuclear & $72(75.8 \%)$ & $14(14.7 \%)$ & & & $82(86.3 \%)$ & $4(4.2 \%)$ & & \\
\hline Joint & $6(6.3 \%)$ & $3(3.2 \%)$ & 1.613 & 0.204 & $8(8.4 \%)$ & $1(! .1 \%)$ & 0.682 & 0.409 \\
\hline \multicolumn{9}{|l|}{ No of Abortion } \\
\hline 0 & $14(14.7 \%)$ & $0(0 \%)$ & & & $14(14.7 \%)$ & $0(0 \%)$ & \multirow{4}{*}{7.297} & \multirow{4}{*}{0.063} \\
\hline 1 & $12(12.6 \%)$ & $4(4.2 \%)$ & 17.497 & 0.001 & $13(13.7 \%)$ & $3(3.2 \%)$ & & \\
\hline 2 & $52(54 \%)$ & $10(10.5 \%)$ & & & $60(63.2 \%)$ & $2(2.1 \%)$ & & \\
\hline 3 above & $0(0 \%)$ & $3(3.2 \%)$ & & & $3(3.2 \%)$ & $0(0 \%)$ & & \\
\hline \multicolumn{7}{|l|}{ No of Pregnancy } & \multirow{5}{*}{3.709} & \multirow{5}{*}{.295} \\
\hline 1 & $10(10.5 \%)$ & $3(3.2 \%)$ & & & $12(12.6 \%)$ & $1(1.1 \%)$ & & \\
\hline 2 & $53(55.8 \%)$ & $10(10.5 \%)$ & 3.187 & .364 & $61(64.2 \%)$ & $2(2.1 \%)$ & & \\
\hline 3 & $9(9.5 \%)$ & $4(4.2 \%)$ & & & $11(11.6 \%)$ & $2(2.1 \%)$ & & \\
\hline 4 & $6(6.3 \%)$ & $0(0 \%)$ & & & $6(6.3 \%)$ & $0(0 \%)$ & & \\
\hline \multicolumn{7}{|l|}{$\begin{array}{l}\text { Heard about Pap } \\
\text { Test }\end{array}$} & \multirow{3}{*}{.327} & \multirow{3}{*}{.567} \\
\hline Yes & $48(50.5 \%)$ & $17(17.9 \%)$ & 9.556 & .001 & $61(64.2 \%)$ & $4(4.2 \%)$ & & \\
\hline No & $30(31.6 \%)$ & $0(0 \%)$ & & & $29(30.5 \%)$ & $1(1.1 \%)$ & & \\
\hline \multicolumn{7}{|c|}{$\begin{array}{ll}\text { Source } & \text { of } \\
\text { Knowledge }\end{array}$} & \multirow{4}{*}{4.877} & \multirow[b]{2}{*}{.087} \\
\hline Friends / Relatives & $6(6.3 \%)$ & $4(4.2 \%)$ & & & $8(8.4 \%)$ & $2(2.1 \%)$ & & \\
\hline Media & $50(52.6 \%)$ & $4(4.2 \%)$ & 9.985 & .007 & $52(54.7 \%)$ & $2(2.1 \%)$ & & \\
\hline Health Workers & $22(23.2 \%)$ & $9(9.5 \%)$ & & & $30(31.6 \%)$ & $1(1.1 \%)$ & & \\
\hline $\begin{array}{l}\text { Every women } \\
\text { must take pap test }\end{array}$ & & & & & & .021 & .884 & \\
\hline Yes & $47(49.5 \%)$ & 7(7.4\%) & 2.071 & .150 & $51(53.7 \%)$ & $3(3.2 \%)$ & & \\
\hline No & $31(32.6 \%)$ & $10(10.5 \%)$ & & & $39(41.1 \%)$ & $2(2.1 \%)$ & & \\
\hline \multicolumn{8}{|l|}{$\begin{array}{l}\text { Like to know } \\
\text { more about pap } \\
\text { test }\end{array}$} & \\
\hline Yes & $25(26.3 \%)$ & $4(4.2 \%)$ & .478 & .489 & $29(30.5 \%)$ & $0(0 \%)$ & & \\
\hline No & $53(55.8 \%)$ & $13(13.7 \%)$ & & & $61(64.2 \%)$ & $5(5.3 \%)$ & 2.319 & \\
\hline
\end{tabular}

A semi structured questionnaire with questions on social demo graphic data (age, religion, education, occupation, income, marital status, age at marriage, No of pregnancy, family type, Contraception used, No of abortion, heard about pap test, source of knowledge, every women must be take pap test).

The reliability of the questionnaire was tested in a sample, same of 10 samples demonstrating a high level of reliability.

Researcher adapted following definition in the women knows about Pap test for detect cancer consider adequate knowledge, not known about Pap test considered inadequate knowledge. All statistical analysis was used test was set at $\mathrm{P}<0.05$. The test was to assess the association between two qualitative variables. The chi square test used for analysis to estimate the risk of different factors for inadequate knowledge of Pap test smear test "0" for inadequate, "1" for adequate knowledge. For attitude, rating scale was used, for direct questions positive scoring and indirect questions negative scoring was given.

\section{Results and Discussion}

The frequency percentage distribution of demographic variables of women shows with respect out of 95 women majority of them 30 
(31.6\%) to the age group of 31 to 40 years. Related to majority of the women belongs Hindu 72(75.8\%).

In accordance to education majority of the women belongs to secondary education $39(41.1 \%)$, In regarding occupation most of the women belongs to home maker $56(58.9 \%)$ (Table 1).

Related to income majority of the women Rs.5001-10000/-, below income of $33(34.7 \%)$, Related to marital status majority of the women $87(91.6 \%)$ are married.

In related to age at marriage majority of the women $66(69.5 \%)$ with the age of 20 to 25 , regarding no of pregnancy $63(66.3 \%)$ of them says 1 pregnancy, regarding to type of family $86(90.5 \%)$ of women from nuclear family, In relation to contraceptive use $73(76.8 \%)$ women says yes, with respect to heard about cervical cancer screening test 65(68.4\%), were already heard. In related to source of knowledge majority of them got information through media 54(56.8\%) With regard question every women must be taken cervical cancer screening test $54(56.8 \%)$ say yes.

In Table 2, regarding knowledge majority, $77.9(82 \%)$ of the women had inadequate knowledge; $17.2(18.10 \%)$ of the women had moderate knowledge and none of them had adequate knowledge

Regarding the level of attitude 89.9 (94.6\%) of the women had inadequate attitude 5 $(5.26 \%)$ of the women had moderate attitude and No women had positive attitude on cervical cancer screening.

Table 3 shows the association of the level of knowledge and attitude with their selected demographic variables. There is significant association between the level of attitude and religion, education, No of pregnancy, contraceptive used, No abortion, heard about pap test, source of knowledge.

The study concluded that women are with inadequate knowledge and no positive attitude towards cervical cancer screening. So, the researcher felt the need of women and distributed the pamphlets which contain information about the cervical cancer and its management including screening. Apart from that, the study was very interesting, the participants were very co-operative and eagerly asked many questions. The researcher clarified their doubts. The researcher encouraged the participants to spread the knowledge about the cervical cancer screening to their friends and relatives, which may create awareness among the people to prevent the cervical cancer in future. Researcher felt proud about the contribution to some extend in reducing the occurrence of cervical cancer.

\section{References}

Abdullah F.G (1986) "Better patient care through research" $1^{\text {st }}$ edition, New York, Macmillan Company.

Adele pillitery (2002), maternal and child health nursing ( $5^{\text {th }}$ edition $)$

Philadelphia, Lippincott Williams and Wilkins publications.7.

Anuradhamathu (2005) “women's health - A major Area of concern's social welfare”, 52(1)5.

Arm Maries Tommy (2006), Nursing theories and their work ( $6^{\text {th }}$ edition) Missouri, Mosby Publications.

Beret, J.S (1996) Novak's Gynecology (12 ${ }^{\text {th }}$ edition) Philadelphia Williams and Wilkins publication.

Defreitas, SL, Aerates SL and SM Debarros (1998),"concur nursing "International Journals of Gynecological cancer 22(5)401-5. 
Jensen M.D and I.M Bobak (1985) maternity and gynecologic care of the Nurse and Family ( $3^{\text {rd }}$ edition) Toronto C.V Mosby Company.

Miaskowshi. C and Buchse. P (1999) Oncology Nursing, assessment and clinical care $\left(1^{\text {st }}\right.$ edition) Missouri Mosby publications.

Rengaswamy Sankaranayanan, M.D., (2009) HPV Screening for Cancer Cervix in rural India, The New England Journal of Medicine, 360:1385-1394.

Robbins, Cotran, Kumar, (1989) Pathologic basis of disease, $4^{\text {th }}$ edition, Tokyo, W.B. Saunder Company, 1147-1167.

Sinha R, (2003) Cancer risk and diet in India, Journal of Post graduate medicine, vol. 49, Issue 3, pg. 222-228.

WHO, (2006) Comprehensive cervical cancer control: A guide to essential practice, WHO Publication.

\section{How to cite this article:}

Thavamani, K. and Susila, C. 2018. Knowledge, Attitude Related to Cervical Cancer Screening among Women. Int.J.Curr.Microbiol.App.Sci. 7(05): 3718-3725.

doi: https://doi.org/10.20546/ijcmas.2018.705.430 